\title{
THE IMPLEMENTATION OF RECIPROCAL TEACHING MODEL TO IMPROVE STUDENTS' ACHIEVEMENT ON ACID-BASE CONCEPTS
}

\author{
Maysara $^{1 *}$, Habiddin ${ }^{2}$ \\ Prodi Pendidikan Kimia, Universitas Haluoleo, Kampus Bumi Tridharma, Anduonohu, Kendari, \\ Southeast Sulawesi, Indonesia 93123 ${ }^{1)}$ \\ Chemistry Department, Universitas Negeri Malang, Malang, East-Java-Indoensia ${ }^{2)}$
}

\begin{abstract}
This study aimed to describe the improvement of students' learning outcomes using reciprocal teaching model. The improvement is measured based on the results of pre-test and posttest. 24 students of XI class at SMA Negeri 4 Wangi-Wangi taking sciences major participated in this study. This one group pre-test \& post-test research design used an instrument (test) in the form of multiple choice questions. The questions were constructed by considering the cognitive level in Bloom taxonomy. The study reveals that students' improvement falls in the moderate category with the $\mathrm{N}$-gain score of 0.69 . The study also uncovered that students' ability in answering questions decreases with the increase in the cognitive level of the questions.
\end{abstract}

Keywords: reciprocal teaching, acid-base, students' achievement, learning outcomes

\section{INTRODUCTION}

Students' understanding of chemistry concepts has been a concern in science education research, particularly in the chemistry education discipline. In many secondary schools, chemistry teaching generally rises many difficulties for many reasons. The nature of chemical concepts as well as human issues is considered as the reason rooting those difficulties (Enero Upahi \& Ramnarain, 2019). The same issue was also found in SMA Negeri 4 Wangi-Wangi (a public secondary school in Wakatobi Regency, Southeast Sulawesi, Indonesia). The school has a high commitment to producing knowledgable and skilful students through an innovative teaching method including in chemistry teaching. Based on an interview conducted by one of the authors to the chemistry teacher at the school, students' grades in chemistry subject generally were still far below the minimum grade standard (Kriteria Ketuntasan Minimal/KKM in Indonesian language) as determined by the Ministry of Education, Republic of Indonesia which is 75.00 out of 100. For instance, the KKM grades for the topic of acid and base were 61.23 and 65.74 for the academic years of 2013 and 2014 consecutively. It is revealed that the issue is caused by students' low motivation and they tend to be passive in the class. In addition, the teaching method applied in chemistry teaching at the school was dominated by direct instruction. The instruction commonly initiated by teacher explains concepts and followed by providing some exercises for students. In this method, the teacher is likely to transfer his/her knowledge to students by 'telling' students and applies a direct procedure to ensure that the knowledge has been received by students (Davis, 2018). This approach clearly strengthens the condition that students passively receive information and try to memorize it as long as he/she can.

\footnotetext{
${ }^{*}$ Corresponding author: Prodi Pendidikan Kimia, Universitas Haluoleo, Southeast Sulawesi 93123, Indonesia. Email: maysara.salam@ymail.com
} 
Implementing a more challenging teaching method such as reciprocal approach rather than regularly using direct instruction could be a reasonable effort in order to switch students' common behaviour from passive to be more active. Reciprocal teaching method which is initially applied in literature discipline particularly in reading comprehension (Ashegh Navaie, 2018; Okkinga, van Steensel, van Gelderen, \& Sleegers, 2018) is an instructional method for improving students' reading comprehension skills. This model even named as reciprocal reading in some literature (Gilbert, 2018). Later, the teaching approach has been adopted in the teaching and learning in the wider disciplines including in science/chemistry teaching. However, attention to do research regarding the implementation of reciprocal teaching should be carried out in wider samples (Okkinga et al., 2018). The Fab Four strategy including summarizing, questioning, predicting, and clarifying is frequently applied in implementing this model (Ashegh Navaie, 2018; Bales, 2019).

\section{METHOD}

This study involved 24 students taking science major at SMAN 4 (Senior High School) WangiWangi, Wakatobi Regency, Southeast Sulawesi. Data collection was carried out in February 2015. One group pre-test \& post-test design as shown in Figure 1 below was applied in the study.

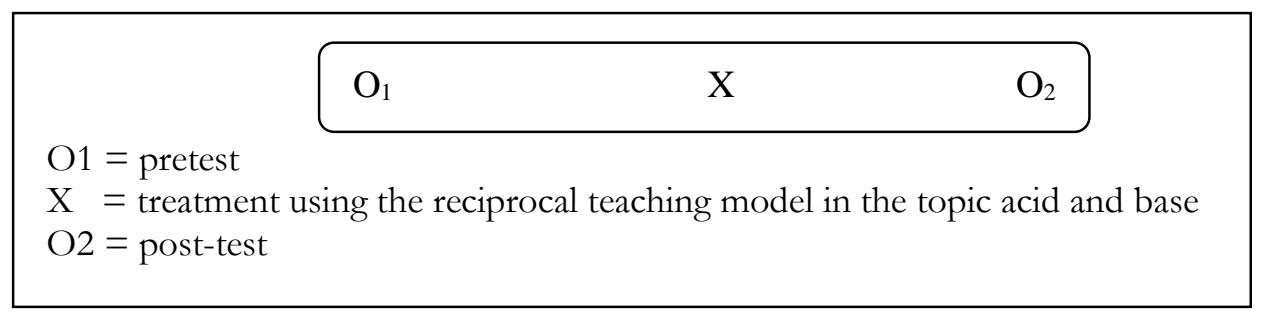

Figure 1. Research design

The instrument used for data collection was the acid-base test in the form of 20 multiple choice questions. 3 questions (no. 1, 2 and 3) are considered as knowledge level (C1) in the Bloom taxonomy. 7 questions which were no 4, 5, 6, 7, 8, 9 and 11 are considered as comprehension level (C2) and the remain questions $(10,12,13,14,15,16,17,18,19$ and 20) are categorized as application level (C3). Observation sheets to record students and teacher activities were also applied during the implementation of the reciprocal teaching model. The data were analyzed descriptively. N-gain score to measure the improvement of students' grade between pre and post-tests was also applied.

\section{RESULTS AND DISCUSSION}

The difference in students' grade between pre-test and post-test on the topic of acid-base is displayed in Tabel 1 below. The average of students' grades in each cognitive level of question is also depicted in the table.

Table 1 shows that students' ability in answering $\mathrm{C} 1$ questions is the highest among the three cognitive levels both in pre-test and post-test. In the post-test, students' grade average is quite high with 80 and being the highest among other cognitive levels (C2 and C3) for the pre-test. Students' grade for $\mathrm{C} 1$ in the post-test is the peak for all levels both in the pre-test and post-test with 100 meaning all students answered all the $\mathrm{C} 1$ questions correctly in the post-test. These results confirm that students ability in answering $\mathrm{C} 1$ questions is sufficient.

The C3 questions are considered as the most difficult one both in the pre-test and post-test. In the pre-test, students' grade average for this level is only 17. In post-test, the grade is better with 66 but still the lowest among all levels. Students' grade for C2 questions was always higher than that of for $\mathrm{C} 3$ but lower than $\mathrm{C} 1$ questions both in the pretest and post-test. 
Table 1. The average students' grade in answering the acid-base questions.

\begin{tabular}{ccccc}
\hline \multirow{2}{*}{ Cognitive level } & \multicolumn{2}{c}{ Students' grade average (out of 100) } & \multicolumn{2}{c}{ Standard deviation } \\
\cline { 2 - 5 } & pre-test & post-test & pre-test & post-test \\
\hline C1 & 80 & 100 & 19,4 & 0 \\
C2 & 24 & 86 & 14,2 & 13,9 \\
C3 & 17 & 66 & 11,9 & 11,7 \\
\hline Total & 29 & 78 & 7,0 & 6,8 \\
\hline
\end{tabular}

C1: Knowledge

C2: Comprehension

C3: Application

In all cognitive levels of questions, students' grade showed a significant improve from pretest to post-test. The highest improvement was shown in the C2 questions with 64 points. Students' grade in the C3 question also improved significantly with 49 points. When all the questions are considered simultaneously, students' grade improvement is still considered high with 48 points. These improvements were confirmed by the N-Gain score as depicted in Table 2 below.

Table 2. The N-gain score for each cognitive level of questions

\begin{tabular}{ccccc} 
& \multicolumn{4}{c}{ N-Gain } \\
\cline { 2 - 5 } & Average & Standard Deviation & Minimum & Maximum \\
\hline C1 & 1,00 & 0,00 & 1,00 & 1,00 \\
C2 & 0,83 & 0,18 & 0,39 & 1,00 \\
C3 & 0,58 & 0,14 & 0,28 & 0,87 \\
\hline Total & 0,69 & 0,09 & 0,53 & 0,92 \\
\hline
\end{tabular}

The highest $\mathrm{N}$-gain score is shown for $\mathrm{C} 1$ questions with 1.0 that falls in the high category. For C2 and $\mathrm{C} 3$ questions, the $\mathrm{N}$-gain scores are 0.83 and 0.56 respectively. These scores confirm that the improvement in students' grades for $\mathrm{C} 1$ and $\mathrm{C} 2$ question levels fall in the high category but a moderate category for C3 questions. In total, the improvement of students' grade on the topic of acid-base falls in the moderate category with a significant N-Gain (0.69). These improvements could be attributed to the contribution of the reciprocal teaching method and imply that this teaching model is effective in improving students' ability in answering acid-base questions particularly for C1 and C2 levels. In a more advanced study, it is uncovered that scaffolding among with sharing, feedback, and discussion boosted students' achievement of biochemistry and even train students' mental model to be able transfering macroscopic to submicroscopic representations (Erman, Liliasari, Ramdani, \& Wakhidah, 2019).

The high contribution of the reciprocal teaching model in improving students grades in this study could be explained as the following. This model allows students to act as a teacher/ an instructor at some points. This role emphasizes students to teach each other and directly and/or indirectly will improve their understanding of the subject (Gilbert, 2018). In addition, the steps involving in reciprocal teaching models allow students to be more responsive for their understanding and finally to train them to be independent and self-regulated learning. For instance, in doing clarification as a response to questions from his/her colleagues and/or teacher, students should explore some learning materials to answer the question. In the same time, students will put his/her efforts to clarify and select the most possible and appropriate answer.

The most significant improvement in this study was still demonstrated in students grade for C1 questions, but this impact could be a starting point to explore the teaching-learning to be more challenging. Students' knowledge of several definitions, terminology or others attributes related to acid-base concepts will help them to be more successful in the next step of learning involving a 
more advanced level of thinking. The contribution of this study to the improvement acid-base teaching may just below average. However, this can be taken into account when a chemistry educator keen to provide various teaching approaches to his/her students. A chemistry teacher in a secondary school in particular is highly recommended to prepare his/her students with sufficient basic chemical concepts as their prior knowledge before they embark to the university education. Students' preconceptions before entering higher education is timely for their study success (Habiddin \& Page, 2019).

\section{CONCLUSION}

The results show that students' grade increased significantly as shown by the result of pretest and post-test, particularly for C1 questions level. Students' grade improvement falls in the moderate category with the N-Gain score average of 0,69 . This implies that reciprocal teaching model significantly increases students' grade in answering acid-base questions for C1 and C2 levels in particular. However, this teaching model can be considered to be applied to a more advanced level of thinking. Referring to the cognitive level of the questions, students' ability to answer the questions correctly decreases with the increase in the cognitive level of the questions. This implies that students' learning outcomes decrease with the increase in the cognitive level of questions.

\section{REFERENCES}

Ashegh Navaie, L. (2018). The Effects of Reciprocal Teaching on Reading Comprehension of Iranian EFL Learners. Advances in Language and Literary Studies; Vol 9, No 4 (2018). https://doi.org/10.7575/aiac.alls.v.9n.4p.26

Bales, K. (2019). Reciprocal Teaching: Definition, Strategies, Examples. Retrieved from https://www.thoughtco.com/reciprocal-teaching-definition-4583097

Davis, A. (2018). Evidence-based approaches to education: Direct instruction, anyone? Management in Education, 32(3), 135-138. https://doi.org/10.1177/0892020618765421

Enero Upahi, J., \& Ramnarain, U. (2019). Representations of chemical phenomena in secondary school chemistry textbooks. Chemistry Education Research and Practice, 20(1), 146-159. https://doi.org/10.1039/C8RP00191J

Erman, E., Liliasari, L., Ramdani, M., \& Wakhidah, N. (2019). Addressing Macroscopic Issues: Helping Student Form Associations Between Biochemistry and Sports and Aiding Their Scientific Literacy. International Journal of Science and Mathematics Education. https://doi.org/10.1007/s10763-019-09990-3

Gilbert, F. (2018). Riding the Reciprocal Teaching Bus. A Teacher's Reflections on Nurturing Collaborative Learning in a School Culture Obsessed by Results. Changing English, 25(2), 146-162. https://doi.org/10.1080/1358684X.2018.1452606

Habiddin, H., \& Page, E. M. (2019). Development and Validation of a Four-Tier Diagnostic Instrument for Chemical Kinetics (FTDICK). Indonesian Journal of Chemistry, 19(3), 720-736. https://doi.org/https://doi.org/10.22146/ijc.39218

Okkinga, M., van Steensel, R., van Gelderen, A. J. S., \& Sleegers, P. J. C. (2018). Effects of reciprocal teaching on reading comprehension of low-achieving adolescents. The importance of specific teacher skills. Journal of Research in Reading, 41(1), 20-41. https:// doi.org/10.1111/1467-9817.12082 